\title{
PRESERVING ORTHODOX CHRISTIANITY IN THE DIASPORA: THE MISSION OF THE CHURCH IN THE FACE OF A POST-MODERN CULTURE
}

Mark J. Cherry*

\section{Introduction}

Western Christianity lies in ruins. A secular orthodoxy is being established to fill the vacuum. This newly dominant secular culture discounts all claims to a uniquely true, canonical account of moral rationality and human flourishing. Everything is approached as if all were without ultimate meaning. All claims to moral truth are being deflated, reduced to socially and historically conditioned judgments, culturally relative virtues, or personal intuitions. Guided by an atheistic methodological postulate, this secular culture is being embedded in and enforced at law. Orthodox Christianity's confession of absolute truth in Christ has become profoundly politically incorrect. As a consequence, the Orthodox diaspora must resolutely face two interrelated goals: 1) how to preserve themselves and their children as fully Orthodox and 2) how effectively to convert others to Christ.

To accomplish these goals, Orthodox Christians must learn to see themselves as fundamentally distinct. We must understand ourselves as set apart from the secular world. For example, Orthodox Christianity knows the deep sinfulness of actions that the secular culture embraces (e.g., abortion, fornication, homosexual marriage). Moreover, although other Christian religions may at times appear to

\footnotetext{
* PhD., The Dr. Patricia A. Hayes Professor in Applied Ethics, Professor and Chair, Department of Philosophy, St. Edward's University, Austin, Texas.
} 
be talking about the same things as Orthodox Christianity, they are not. The moral theology of Protestants and Roman Catholics is guided by heterodox religious assumptions. Moreover much of their theology is routinely oriented towards ecumenism and has been radically deflated. Many supposedly "Christian theologians" now seek to accommodate the secular culture, rather than to transform it to Christ.

As this paper argues, Orthodox Christians must understand how radically different a truly Christian life is from the life-world that surrounds them. If we are to maintain Orthodox Christianity for our children and grandchildren, and with love to convert others, we must fully preserve the Holy Orthodox Church and the life-world of Orthodox Christianity; a life embedded in right worship and right belief, properly oriented vigils, fasting, and almsgiving.

\section{A Weakened and Shifting Moral Theology}

Where Orthodox Christianity recognizes that morality must be appreciated in terms of an authentic experience of God, for secular culture God is dead. As a result, secular morality lacks any ultimate foundation or final point of moral focus to ground ethical judgments. In its denial of God, the secular world has lost any in principle standpoint from which to provide a unique and binding moral perspective. It is, as Gianni Vattimo concludes, a cultural Babel. ${ }^{1}$ Without God, definitive moral content cannot be secured. The very project of morality is thereby radically transformed. Secular morality can encompass no more than those particular idiosyncratic ends and projects that individuals affirm as if they were virtuous and good. This is why the secular world tends to embrace an individualist search for self-satisfaction. Lacking either canonical foundation or definitive content, secular morality has been deflated into no more than the affirmation of those lifestyle choices that are currently

\footnotetext{
1 "The West is a synonym for consumerism, hedonism, a Babel-like pluralism of cultures, loss of center, and obliviousness to any reference to 'natural' law" (Vattimo, 2002, p. 70).
} 
popular or otherwise affirmed as political correct (Engelhardt 2010a; 2010b).

Much of Mainline Protestant and Roman Catholic moral theology has also been deflated. Proponents have adopted a shift in tone and emphasis that ceases to take seriously either God's commands or that Christianity must stand in opposition to the secular culture. Rather than underlining the obligation given in the Gospel of Matthew (28:19-20) to convert the world: "Go therefore and make disciples of all the nations, baptizing them in the name of the Father and of the Son and of the Holy Spirit, teaching them to observe all things that I have commanded you," moral claims are often articulated in terms of what one might call "weak theology"; i.e., a form of post-modernism, that requires a radical toning down of theological claims, together with the avoidance of affirming an objective moral good or objectively true moral theology (Vattimo 1982, 2002; Engel 2001; Robbins 2004a, 2004b). Such a "weak theology" puts solidarity and social justice prior to truth and dogma. As Vattimo writes: "What project can I have in the world if I am a Christian? To defend the authority of the church and its dogmas, or to strive for a different situation, an ecumenical situation, a situation in which we really come together and feel mutual affection" (Vattimo \& Girard 2010, pp. 41-42). For Pope Francis, for example, this appears to mean that one accepts adulterers and homosexuals within the church prior to underscoring the sinfulness of adulterous and homosexual acts. Of course, this itself fails to recognize the difference between the love Christians must show to sinners and the constraints they must impose before someone is allowed to receive communion. It does not require that one confront secular morality, much less that one convert the world to Christ, teaching all people to follow His commands. The connection to authentic Christianity and the lives of the Fathers is tenuous at best.

Central to such forms of analysis is the deflation of moral theological claims. One is encouraged to embrace an ecumenical openness to the potential goods of alternative lifestyles (e.g., homosexual unions), as well as to other religions and spiritual points 
of view (e.g., heterodox Christian religions and new age paganism). Moral statements may still be made, but they are to be stated without any emphasis on dogmatic certainty and with a willingness to accept the moral perspectives of others. For example, it has become very politically incorrect to affirm that all should recognize that abortion is the murder of a child in the womb. Instead, one is politically pressured to say that "abortion is the wrong choice for me". The second statement may be true, but the real moral and spiritual significance of taking human life has been subdued.

This shift in tone and emphasis typically also involves a greater accent on secularly acceptable left-of-center political themes, from critiques of capitalism, ${ }^{2}$ to populist affirmations of human dignity, ${ }^{3}$ worker's rights, ${ }^{4}$ and political action on global warming. ${ }^{5}$

2 When addressing economic issues in Evangelii Gaudium, Pope Francis adopts a populist, social democratic tone, attacking "... the absolute autonomy of the marketplace" (Francis 2013, p. 47, \# 56), lamenting that "today everything comes under the laws of competition and the survival of the fittest" (Francis 2013, p. 45, \#53), while also advancing vague reasons for envy and distrust of others. He criticizes, for example, so-called "trickle-down" economics as having a "crude and naive trust in the goodness of those wielding economic power and in the sacralized workings of the prevailing economic system" (Francis 2013, p. 46, \#54). Such generalizations are rhetorically powerful, but highly misleading. An unregulated market exists nowhere in the world. Moreover, as others have noted, countries that achieve high levels of economic freedom consistently perform better than those with less economic freedom through long term prosperity which measurably abounds to the benefit of the poor (Miller 2014, A13).

3 "Demands involving the distribution of wealth, concern for the poor and human rights cannot be suppressed under the guise of creating a consensus on paper or a transient peace for a contented minority. The dignity of the human person and the common good rank higher than the comfort of those who refuse to renounce their privileges" (Francis 2013, p. 168, \# 218).

$4 \quad$ "We are not simply talking about ensuring nourishment or a 'dignified sustenance' for all people, but also their 'general temporal welfare and prosperity'. This means education, access to health care, and above all employment, for it is through free, creative, participatory and mutually 
Indeed, this movement appears to be politically driven to uproot and change Christianity. For example, although he was cautious in his statements, in a speech at the University of Notre Dame, Gerhard Cardinal Müller, Prefect of the Congregation for the Doctrine of the Faith of the Catholic Church, affirmed that some form of liberation theology has become the guide for Roman Catholicism (Octber 31, 2014). Historically, liberation theology has played a key role in the transformation of Roman Catholicism and Protestantism.

Christian theology continues to be transformed. Recently, a shift in theological paradigm has occurred through the growth of liberation theologies. This paradigm shift in theology that all liberation theologies have wrought characterizes the lifeblood of change in theology. Feminist, womanist, mujerista, Latina, Asian, Native American and queer theologies are all forms of liberation theology, among which we also find Latin American and black liberation theologies. Although every form of liberation theology is different in its specific characteristics, a central feature of each is its press for liberation from all forms of oppression, given the gracefilled message of the gospel (Streufert, 2010, p. 3).

This is not the Orthodox Christianity of the Divine Liturgy, in which we sing, "We have seen the true light, we have received the heavenly Spirit; we have found the true faith, worshipping the undivided Trinity: for $\mathrm{He}$ hath saved us" (Antiochian Orthodox Christian Archdiocese, 1997, p. 123). Orthodoxy's recognition of the one True God and His one Holy Apostolic Church is profoundly at odds with such a deflation and alteration of Christianity.

supportive labour that human beings express and enhance the dignity of their lives. A just wage enables them to have adequate access to all the other goods which are destined for our common use" (Francis 2013, pp. 151-152, \# 192).

${ }^{5}$ Pope Francis has recently begun preaching about the dangers of global warming. See http://catholicclimatecovenant.org/catholic-teachings/popefrancis/ 


\section{A Deflated Moral Theology without Sin or Need for Repentance}

Advocates of such a weak theology no longer appreciate why one ought to believe, preach, or follow Orthodox Christian dogma. The reality of God and His commands has been rejected. God is no longer appreciated as in authority to provide a definitive account of the right, the good or the virtuous. Instead, they seek "solidarity" and "social justice" rather than Christian truth (Vattimo \& Girard 2010, p. 51). The goal is actively to recast traditional Christian norms.

In part, Christian moral norms have come to be appreciated as the artificial product of particular times and places, malleable, and subject to re-interpretation. As Gianna Vattimo argues: "[We] experience the return of the religious in a world in which one cannot ignore the history of influence of every text, and of the biblical text above all. One cannot ignore the fact that the sacred texts which mark our religious experience are handed down to us by a tradition, by which I mean also that its mediation does not allow them to survive as unmodifiable objects ..." (1998, p. 88). According to Vattimo, everything associated with "... the tradition and truth of Christianity is dispensable and may rightfully be called mythology" (Vattimo, 2007, p. 41). ${ }^{6}$ Morality has become largely a matter of individual choice or social convention. As Richard Rorty (19312007) puts it: 'In a 'weak' conception, morality is not a matter of unconditional obligations imposed by a divine or quasi-divine authority but rather is something cobbled together by a group of people trying to adjust to their circumstances and achieve their goals by cooperative efforts" (Rorty, 2004, p. xviii). Traditional moral constraints have been de facto left behind.

${ }^{6}$ Richard Rorty notes that recasting moral theology in this fashion produces what he terms: "... a desirable humility about our own moral intuitions and about the social institutions to which we have become accustomed. This humility will encourage tolerance for other intuitions, and a willingness to experiment with ways of refashioning or replacing institutions" (Rorty, 2004, xviii-xix). 
Consider, for example, the Christian condemnation of homosexual acts. When one espouses a weak theological position, one avoids underscoring the intrinsic sinfulness of sex outside of the monogamous marriage of man and woman. Instead, as noted, one argues in favor of the potential goods of different lifestyle choices, and the importance of avoiding discrimination. Lutheran scholar Jillian Cox argues, for example, that the morality of homosexual acts should be rethought in terms of "... a contemporary notion of committed, egalitarian, lesbian and gay relationships" (2013, p. 369). ${ }^{7}$ Cox asserts: "Queer theologies expose the fact that much Christian theology has been based upon the assumption of a particular kind of love and sexual expression as universally normative..." (2013, p. 370). Frank Bruni of the New York Times concludes more aggressively: "....church leaders must be made "to take homosexuality off the sin list"' (2015, p. SR3, my emphasis). Homosexual acts, such advocates conclude, should not be understood as sinful and Christianity ought to bless homosexual marriage. Cox urges Christians to embrace "an understanding of sin that recognizes individual agency and exposes homophobic ideologies as sinful" (Cox, 2013, p. 369). To emphasize, the traditional Christian moral condemnation of sex outside of the marriage of man and woman, has been historically contextualized, judged the prejudice of an unenlightened time, and turned on its head. For such post-modern "Christians", the "sinners" are those who refuse to affirm the virtue of sex outside of the monogamous union of husband and wife. ${ }^{8}$

Consider also Mary Lowe, who asserts that "...[Q]ueer biblical scholars have shown how negative cultural stereotypes about same-sex relations have been preached as God's infallible word. Informed by Romans 1:28, homoerotic attraction is viewed as the result of a person's failure to acknowledge God, and as a consequence, God gives the individual over to "degrading passions"" (Lowe, 2010, p. 73).

8 Mary Lowe argues, for example, that traditional Christian moral positions on sexuality must be overthrown: "Another problem is that sexual sins are said to pollute and defile the body in a way that other sins do not. Paul wrote, 'Every sin that a person commits is outside the body, but the 
In part also, rather than requiring submission to God, He Who is Holy, and His commands, individuals are advised to follow the guidance of their own conscience. In his Evangelii Gaudium, Pope Francis argued that "Non-Christians, by God's gracious initiative, when they are faithful to their own consciences, can live 'justified by the grace of God,' and thus be associated to the paschal mystery of Jesus Christ" (Francis 2013, p. 189, \# 254). Francis made no reference to an appropriately objective standard through which to judge the propriety of one's choices, or of the serious need to repent for having followed one's conscience to evil ends. Indeed, no mention was made of the fact that much of the "good" which secular morality utilizes to guide individual conscientious choice, Orthodox Christianity knows to be deeply sinful. Kathryn Reinhard urges, for example, that one ought to evaluate homosexual acts, homosexual unions, and the potential "holiness" of such lifestyles, through one's conscience. "Rather than understanding homosexuality as a matter of 'sin,' the churches of the Anglican Communion would be better served by considering it as a matter of "conscience" (Reinhard, 2012, p. 425). Reinhard seeks to dismiss the clear force of St. Paul in Romans 1:26-27:

For this reason God gave them up to vile passions. For even their women exchanged the natural use for what is against nature. Likewise also the men, leaving the natural use of the women, burned in their lust for one another, men with men committing what is shameful, and receiving in themselves the penalty of their error which was due.

fornicator sins against the body itself (1 Cor 6.18). When reflecting on Romans 1, Luther also claimed that certain sexual sins lead to physical pollution: "Those who do not acknowledge God ...should be catapulted into the lowest and the worst uncleanliness, that they have not only an unclean heart ... but also an unclean body". Anything outside of heterosexual relations in marriage, Luther thought, led to an unclean heart, which led to an unclean body. All of these accusations of sin create emotional hardship and physical danger for LGBTQI persons" (2010, p. 74). 
Christian understandings of sexual morality and marriage have been deflated and wrongly framed as matters of personal preference and individual conscience.

In short, the right, the good, and the virtuous have been reduced to the idiosyncratic and socially influenced choices of individual persons and historically conditioned cultural norms. Various ways of grappling with sexuality, are judged as implying no more than diverse expressions of personally satisfying lifestyles and individual conscientious choice. This weakening of moral theology rejects God as an all knowing lawgiver. It embraces an ecumenical openness to the moral perspectives of others, while also deflating traditional Christian concerns into the prejudices and social artifacts of past times and places. Having undermined knowledge of God as mere "mythology", Orthodox Christians, who know that God lives and that He commands, are also dismissed as irrelevant (Vattimo, 2007, p. 41).

\section{A God Who Commands}

Orthodox Christianity recognizes that all of morality must be appreciated in terms of an encounter with and an authentic experience of God. Once again, consider the examples of sexuality and marriage. Rather than attempting to legitimize homosexual unions, Traditional Christianity knows that the marriage of husband and wife provides for the uniquely appropriate expression of sexual desire, and the proper union for the raising of children. Christian marriage is a sacramental mystery; it is to be unique, monogamous, and holy. St. Gregory Palamas (1296-1359) summarizes: "If, however, you do not choose to live in virginity and have not promised God that you will do this, God's law allows you to marry one woman and to live with her alone and to hold her in holiness as your own wife (cf. I Thess. 4:4), abstaining entirely from other women" $(1995$, p. 328). Marriage is the union of husband and wife in both companionship and reproduction. It is not reducible to an exchange of promises, nor is it a contractual relationship among 
persons. The marriage ritual reveals God joining man and woman together into "one flesh":

O God most pure, the Creator of every living thing, who didst transform the rib of our forefather Adam into a wife, because of thy love towards mankind, and didst bless them, and say unto them: Increase, and multiply, and have dominion over the earth; and didst make of the twain one flesh; for which cause a man shall leave his father and mother and cleave unto his wife, and the two shall be one flesh... (Antiochian Orthodox Christian Archdiocese 1996, p. 295). ${ }^{9}$

Properly understood, marriage is not merely a legal or affective partnership, but holy matrimony. It is a divine institution.

Orthodox Christianity likens marriage to the reunification of Adam and Eve in the man and woman, who are joined to each other. ${ }^{10}$ St. Ignatius of Antioch (second bishop of Antioch c. A.D. 69) reminds Christians: "It is fitting for men and women who marry to be united with the bishop's consent, so that the marriage may be related to the Lord, not to lust. Everything is to be done in God's honor" (1978, p. 118). The relationship between husband and wife is framed in terms of Christ's relationship to His Church: a union of

9 Christ speaks directly to this point regarding marriage: "And He answered and said to then, "Ye read, did ye not, that the One Who made them from the beginning "made them male and female," and said, "On account of this a man shall leave father and mother, and shall cleave to his wife, and the two shall be one flesh"? Therefore they are no longer two, but one flesh"' (Matt 19:4-6).

${ }^{10}$ St. John Chrysostom (347-407) emphasizes, for example, that the drive of men and women to marry is rooted in God's drawing of Eve from Adam: "For there is no relationship between man and man so close as that between man and wife, if they be joined together as they should be.... For there is a certain love deeply seated in our nature, which imperceptibly to ourselves knits together these bodies of ours. Thus even from the very beginning woman sprang from man, and afterwards from man and woman sprang both man and woman. Perceivest thou the close bond and connection? ... For there is nothing which so welds our life together as the love of man and wife" (Chrysostom, Homily XX on Ephesians, 2004, p. 143) 
love and submission and life in Christ. This means that the marital relationship should aim the couple and their family towards God. The union of husband and wife is properly focused on the journey of husband and wife toward holiness. St. John Chrysostom stresses that Christian marriage is a spiritual endeavor:

This then is marriage when it takes place according to Christ, spiritual marriage, and spiritual birth, not of blood, nor of travail, nor the will of the flesh. ... Yea, a marriage it is, not of passion, nor of the flesh, but wholly spiritual, the soul being united to God by a union unspeakable, and which He alone knoweth. Therefore he saith, "He that is joined unto the Lord is one spirit" (Homily XX on Ephesians, 2004, p. 147).

As Aleksei Khomiakov (1804-1960) summarizes:

[T] he Holy Church teaches that God's grace, which blesses the succession of generations in the temporal existence of the human race and the holy union of husband and wife for the formation of a family, is a mysterious gift, which places upon its recipients the lofty obligation of mutual love and spiritual holiness, through which the sinful and material is clothed in righteousness and purity (1998a, p. 43).

During the marriage ritual, the Orthodox priest asks God to bless the couple with a joyful, healthy, fruitful, and lengthy marriage:

..Grant them fair children, and concord of soul and body; exalt them like the cedars of Lebanon, like a luxuriant vine, that having sufficiency in all things they may abound in every work that is good and acceptable unto thee. And let them behold their children's children round about their table, like a newly-planted olive orchard, that, obtaining favor in thy sight, they may shine like the stars of heaven, in thee, our Lord and God... (Antiochian Christian Archdiocese, 1997, pp. 173-174).

This is a deeply sacramental relationship forged with recognition of the headship of the husband and properly oriented towards God. The marriage ritual reminds the couple that they are to be a "small church"; that is, they are "to establish within the family truly Christian relationships, to raise children in faith and life 
according to the Gospel, to be an example of piety for those around one ..." (Pomazanski, 1994, p. 302). Marriage, recognized and blessed by the Holy Church is blessed by God: "For this reason marriage is not a ritual, but a true sacrament. For it is perfected only within the Holy Church, for only in her is anything holy accomplished in full" (Khomiakov, p. 43). Orthodox Christian marriage provides mutual love and support, creating a family oriented in Christian life toward God. Marriage properly appreciated is a partnership in the struggle toward heaven.

Without proper orientation towards God, marriage is no longer Holy Matrimony. If one misrepresents marriage as primarily regarding personal affection or sexual attraction, it becomes much easier to recast it as a civic or legal arrangement aimed at goods in this world, rather than a spiritual unity aimed at salvation. Such a deflation of marriage represents an immanent displacement of the transcendent. In such terms, the secular world, together with a growing number of Roman Catholics and Protestants, finds it all too plausible to affirm same-sex unions and homosexual marriages. Consequently, advocates of the post-modern family affirm a wide variety of "family types", including homosexual unions, non-marital cohabitation, single parents, group living arrangements with open sexual practices and so forth, as equally permissible, and perhaps even good. ${ }^{11}$ Marriage and family life have become just another personal expression of a hedonistic and consumerist culture. However self-pleasing, such living arrangements are but a one sided and incomplete shadow of the proper Christian union of husband and wife.

Orthodox Christianity does not recognize the authority of any independent intellectual enterprise (such as claims to solidarity, social justice, or individual conscience), as in authority critically to

11 In the United States, for example, it is not unusual to live next door to a family comprised of 1) a man and woman (or a same gender couple), who are not necessarily married, 2) the children from the man's previous marriages or sex partners, and 3) the children of the woman's previous marriages or sex partners. 
recast the moral norms given by God. We are not permitted to rewrite the meaning and content of Christianity so as to please the sensitivities of the secular world. ${ }^{12}$ As St. Isaac the Syrian argues, for example, if we are to be truly free we must first recognize sin for the evil that it is, realize that sin enslaves us to our passions, and learn fully to repent.

The man who loves the origins of the passions is an involuntary bondsman, and against his will he is enslaved to the passions. He who hates his sins will cease to sin, and he who confesses them will receive forgiveness. It is impossible for a man to forsake the habit of sin if he does not first acquire a hatred of sin; and it is impossible to receive forgiveness before a confession of iniquities. With the latter, [that is confession,] there is real abasement; and with the former, [that is, hatred of sin,] there is remorse arising from shame that cleaves to the heart (Homily Thirtytwo, 2011, p. 277).

Similarly, Aleksei Khomiakov reminds us that without repentance, sin inherently separates us from God:

But Christ is not only the justice of the Eternal Father. He is also the Father's infinite love. He is not only the condemnation of sin but also the only possible salvation of the sinner. God's nature cannot accept sin because sin is inherently the voluntary separation from God; it is the egoism of the creature who prefers himself to God (Khomiakov, 1998, p. 119).

Rather than accommodating to secular culture, Orthodoxy understands that true freedom lies with confession, repentance for sin, and submission to God.

12 This means that, as Engelhardt, notes, "As a consequence, should the moral requirements of the religious life offend 'ordinary,' that is secular, moral intuitions, sentiments, and settled judgments, then so much the worse for ordinary morality" (Engelhardt, 2007, p. 117). 


\section{Conclusion: Surviving and Flourishing as Orthodox Christians in the Diaspora}

All of life must be appreciated as a struggle to turn from loving oneself, to loving God with all of one's heart, soul and mind, and one's neighbor as oneself, but always in the light of a right-believing and right-worshipping love of God. If Orthodox Christianity is to survive and flourish in the diaspora, Orthodox Christians must learn to understand ourselves as set apart from the lifeworld that surrounds us. As illustrated, ours is a post-Christian, post-traditional age, which embraces moral claims radically at odds with Christian understandings from the Apostles and the Fathers. The West's departure from Orthodox Christianity is evident. It routinely rejects the male priesthood (e.g., ordination of priestesses among Episcopalians, Methodists, and Lutherans), accepts fornication and homosexual acts, while affirming that sex outside of the marriage of man and wife is proper, supports the blessing of homosexual unions and the ordaining of active homosexuals, and in general affirms a permissive pursuit of self-satisfaction, immanent pleasures, and the invention of one's own understanding of a moral lifestyle. In short, the dominant culture of Western world aims us away from God and towards ourselves, to self-satisfaction and self-indulgence.

Orthodox Christians must see themselves as fundamentally distinct. This is a great challenge, because Orthodox Christianity is very much out of step with the dominant secular culture. Orthodox Christians will only survive as Orthodox if they embed themselves and their families in an authentic Christian life of right belief, rightly oriented prayer, fasting, and alms-giving towards God Himself. We must preserve ourselves, our children and grandchildren as fully Orthodox, and with love convert others to Christ in the fullness of Holy Orthodoxy. This means rejecting the siren song of religious ecumenism and political correctness. It means that from the perspective of the dominant secular culture we will look deviant. Remember, however, the Gospel of Saint Matthew: "Blessed are you when they revile and persecute you, and say all kinds of evil against you falsely for My sake. Rejoice and be exceedingly glad, for great is 
your reward in heaven" (Matt 5: 11-12). At all times, we must maintain a vivid understanding of the importance of locating all aspects of life and death within the pursuit of salvation. Adopting the pursuits of the secular world in the hope of popularity and success in this life comes at great cost. As Saint Mark reminds us "For whoever desires to save his life will lose it, but whoever loses his life for My sake and the gospel's will save it. For what will it profit a man if he gains the whole world, and loses his soul?" (Mark 8: 35-36). Our struggle must be fully to preserve the Holy Orthodox Church and the life-world of Orthodox Christianity.

\section{References}

1. Antiochian Orthodox Christian Archdiocese of North America. Service Book of the Holy Orthodox-Catholic Apostolic Church. Isabel Florence Hapgood (trans.) (Englewood Hills, Antiochian Orthodox Christian Archdiocese, 1996.

2. Antiochian Orthodox Christian Archdiocese of North America, The Divine Liturgy of Saint John Chrysostom in Service Book of the Holy Eastern Orthodox Catholic and Apostolic Church (Englewood Hills, Antiochian Orthodox Christian Archdiocese, 1997.

3. Bruni, Frank. "Same Sex Sinners". New York Times, April 5, 2015, p. SR3.s

4. Cox, J. 2013. "The only safe guide is love": Models of engaging Luther's ethical hermeneutic for theological responses to the affirmation of same-sex sexuality. A Journal of Theology 52(4): 365372.

5. Engel, Ulrich. 2001. Religion and violence: Plea for a weak theology in tempore belli, New Blackfriars 82: 558-560.

6. Engelhardt, H.T., Jr. The Euthyphro dilemma reconsidered: A variation on a theme from Brody on Halakhic method. In M. J. Cherry and A. S. Iltis (eds.), Pluralistic Casuistry: Balancing Moral Arguments, Economic Realities, and Political Theory. Springer; Dordrecht, 2007.

7. Engelhardt, Jr., H.T. 2010a. Kant, Hegel, and Habermas: reflections on "glauben und wissen," The Review of Metaphysics 63(2010): 871903.

8. Engelhardt, Jr., H. T. 2010b. Moral obligation after the death of God: 
critical reflections on concerns from Immanuel Kant, G.W.F. Hegel and Elizabeth Anscombe. Social Philosophy and Policy 27(2)(2010): 318-340.

9. Francis, Pope. 2013. Apostolic exhortation Evangelii Gaudium of the Holy Father Francis to the bishops, clergy, consecrated persons and the lay faithful on the proclamation of the Gospel in today's world. Vatican City: Vatican Press.

10. Gregory Palamas, St.. 1995. A New Testament Decalogue. In G.E.H. Palmer, Philip Sherrard and Kallistos Ware (eds. and trans.), The Philokalia, volume 4 (323-330). London: Faber and Faber.

11. Ignatius, St. Letter to Polycarp. In J. Sparks (ed.) The Apostolic Fathers. Minneapolis: Light and Life Publishing Company, 1978.

12. Isaac the Syrian, St. The Ascetical Homilies of Saint Isaac the Syrian, revised second edition. Holy Transfiguration Monastery (trans.) Boston: Holy Transfiguration Monastery, 2011.

13. John Chrysostom, St. Homily XX on Ephesians v.22. In Philip Schaff (ed.), Nicene and Post-Nicene Fathers, first series, vol. 13. Peabody, MA: Hendrickson Publishers, 2004 [1889].

14. Khomiakov, A. The Church is one. In Boris Jakim and Robert Bird (ed and trans.), On spiritual unity: a Slavophile reader (29-54). Hudson: Lindisfarne Books, 1998a.

15. Khomiakov, A. Some more remarks by an Orthodox Christian concerning the Western communions, on the occasion of several Latin and Protestant religious publications (excepts). In Boris Jakim and Robert Bird (ed and trans.), On Spiritual Unity: A Slavophile Reader (117-134). Hudson: Lindisfarne Books, $1998 \mathrm{~b}$.

16. Lowe, M. Sin from a queer, Lutheran perspective. In Mary J. Streufert (ed.). Transformative Lutheran theologies: Feminist, womanist and mujerista perspectives (71-86). Minneapolis: Fortress Press, 2010.

17. Miller, Terry. 2014. America's dwindling economic freedom, Wall Street Journal 263.11 (January 14): A13.

18. Gerhard Cardinal Müller. "Poor for the poor: The mission of the Church: An interview with Gerhard Cardinal Müller. Prefect of the Congregation for the Doctrine of the Faith." University of Notre Dame, October 31, 2014.

19. Pomazanski, M. Orthodox dogmatic theology, S. Rose (trans.). Platina: St. Herman of Alaska Brotherhood, 1994.

20. Reinhard, Kathryn L. Conscience, interdependence, and embodied difference: What Paul's ecclesial principles can offer the 
contemporary church. Anglican Theological Review 94(3) (2012): 403-428

21. Robbins, J. W. Weak theology, Journal of Cultural and Religious Theory 5.2 (2004a): 1-4.

22. Robbins, J. W. In search of a non-dogmatic theology. Aurora, CO: Davies Group, 2004b.

23. Rorty, R. Foreword. In Santiago Zabala (ed.), Nihilism and emancipation: Ethics, politics, and law (ix-xx). New York: Columbia University Press, 2004.

24. Streufert, M.J. Introduction. In Transformative Lutheran theologies: Feminist, womanist and mujerista perspectives (1-14), Mary $\mathrm{J}$. Streufert (ed.) Minneapolis: Fortress Press, 2010.

25. Vattimo, G. Ornamento monumento, Rivista di estetica 12 (1982): $36-$ 43.

26. Vattimo, G. The trace of the trace. In Religion (79-94), J. Derrida and G. Vattimo (eds.). London: Polity Press, 1998.

27. Vattimo, G. After Christianity, Luca D'Isanto (trans.). New York. Columbia University Press, 2002.

28. Vattimo, G. Toward a nonreligious Christianity. In John D. Caputo and Gianni Vattimo. After the Death of God. Jeffrey W. Robbins (ed.). New York: Columbia University Press, 2007.

29. Vattimo, G. and R. Girard. 2010. Christianity, truth, and weakening faith, Pierpaolo Antonello (ed.), William McCuaig (trans.). New York: Columbia University Press. 